\title{
MARI
}

Homepage: http://publisher.uthm.edu.my/periodicals/index.php/mari e-ISSN : 2773-4773

\section{A Review on Modification of Zeolite for Photocatalytic Applications}

\author{
Hazlini Dzinun*1, Mohd Hafiz Dzarfan Othman² \\ ${ }^{1}$ Centre for Diploma Studies (CeDS), \\ Universiti Tun Hussein Onn Malaysia, 84600 Muar, Johor, MALAYSIA \\ ${ }^{2}$ Advanced Membrane Technology Research Centre (AMTEC), \\ Universiti Teknologi Malaysia, 81310 Skudai, Johor, MALAYSIA
}

DOI: https://doi.org/10.30880/mari.2020.01.01.002

Received 00 Month 2020; Accepted 01 Month 2020; Available online 02 Month 2020

\begin{abstract}
Zeolites are microporous crystalline alumina-silicate materials, widely used as catalysts, ion exchangers and adsorbents due to their chemical structure and surface properties. The unique properties of zeolite such as high adsorption capacity and cation exchange make it interesting to be used as a support material. This review article presents the details of various researches of zeolite used as photocatalyst in photocatalytic application. The modifications of zeolite using several methods are described in details for photocatalytic enhancement. The effect of zeolite nanoparticles in membrane fabrication also provided in this article. Furthermore, the efficiency of zeolite used as adsorbents and photocatalyst in the photocatalytic application also presented.
\end{abstract}

Keywords: Zeolite, Microporous, Photocatalytic, Adsorbent, Membrane

\section{Introduction}

Zeolites are three-dimensional, microporous, crystalline solids with well-defined structures which contain aluminium, silicon and oxygen in their regular framework; cations and water are located inside the pores. Zeolites are one kind of natural minerals that are mined in many parts of the world, where most commercialized zeolites are produced synthetically. There are About 50 different types of zeolites with varying physical and chemical properties [1]. Crystal structure and chemical composition are the main differences between them. Zeolites are natural volcanic minerals with a number of unique characteristics. The formation of zeolites is when volcanic ash is deposited in ancient alkaline lakes. The differences between the natural and synthetic zeolites are listed in Table 1.

The efficiency of the photocatalytic process enhancement was affected by the integration of a zeolite host and photoactive sites renders solid photocatalysts where the surface area and the adsorbent capacity were increased. Zeolite based photocatalysts are promising for the abatement of air and water pollution using solar light [2].

Table 1: Differences between natural and synthetic zeolite 


\begin{tabular}{lll}
\hline & Natural & Synthetic \\
\hline Manufacture & $\begin{array}{l}\text { Processed from natural ore } \\
\text { bodies }\end{array}$ & $\begin{array}{l}\text { Manufactured from energy } \\
\text { consuming }\end{array}$ \\
Ratio silica : alumina & Clinoptilolite 5:1 & $1: 1$ (Most hydrophilic) \\
Type & Clinoptilolite & A (Small pore zeolite) \\
& & ZSM-5 (Medium pore seolite) \\
& & Faujasite (X and Y) and \\
& & Mordenite (Large pore zeolite) \\
Potential application & $\begin{array}{l}\text { Do not break down in mildly } \\
\text { acid environment. }\end{array}$ & Can break down in mildly acid \\
& It has more acid resistant & \\
& silica to hold its structure \\
together & \\
\hline
\end{tabular}

\section{Zeolite Fixed Photocatalyst}

New development has been made by Ma and co-workers in 2017 [3]. They developed a strategy for synthesizing eco-friendly photocatalysts using metal oxides serve as photocatalytically active sites and the zeolite micropores use as shape-selective sheath. As stated in $\mathrm{Table}_{2}, \mathrm{TiO}_{2}$ gives complete degradation of the phenol and aniline but not for chlorophyll. It is due to the conventional photocatalyst normally active for the degradation of most organic molecules. The undesirable degradation of chlorophyll occurs and decrease the about $50 \%$ of chrophyll concentration from the original values. However, the zeolite fixed photocatalyst $\left(\mathrm{TiO}_{2} @ \mathrm{~S}-1\right.$ and $\left.\mathrm{Pt} / \mathrm{TiO}_{2} @ \mathrm{~S}-1\right)$ indicates a very interesting result where the concentration of chlorophyll is basically constant over time. It may be due to the superior selectivity of zeolite fixed photocatalyst for the pollutants degradation because the zeolite sheath prohibits the access of chlorophyll to the $\mathrm{TiO}_{2}$ nanoparticles.

The development of eco-friendly photocatalyst will be produced by combining the unique shape selectivity in the degradation with high stability of zeolite fixed photocatalysts. The growth of grasses over the photocatalysts with the observation from the color of leaves was investigated by Ma and coworkers in 2017. Surprisingly, after 20 days of testing, the grass basically kept green in the presence of phenol and aniline pollutants when the zeolite fixed catalysts were added in the system as shown in Figure 1. It had proved that the zeolite fixed catalysts might be harmless to the grass growth. They repeat experiments for many times but similar results were always achieved. They conclude that zeolite fixed catalysts could be regarded as eco-friendly photocatalysts with excellent selectivity for the degradation of pollutants with relatively small molecular sizes.

Table 2: Percentage degradation of selected pollutants under UV and visible light irradiation under four different type of photocatalyst

\section{UV light irradiation}

\begin{tabular}{llll}
\hline & Phenol & Aniline & Chlorophyll \\
\hline $\mathrm{TiO}_{2}$ & $100 \%(120 \mathrm{~min})$ & $100 \%(90 \mathrm{~min})$ & $50 \%(90 \mathrm{~min})$ \\
$\mathrm{TiO}_{2} @ \mathrm{~S}-1$ & $100 \%(150 \mathrm{~min})$ & $100 \%(150 \mathrm{~min})$ & $0 \%(150 \mathrm{~min})$ \\
Visible light irradiation (>400nm) & & \\
\hline \multicolumn{2}{c}{ Phenol } & Aniline & Chlorophyll \\
\hline
\end{tabular}




\begin{tabular}{llll}
\hline $\mathrm{Pt} / \mathrm{TiO}_{2}$ & $100 \%(270 \mathrm{~min})$ & $100 \%(360 \mathrm{~min})$ & $60 \%(360 \mathrm{~min})$ \\
$\mathrm{Pt} / \mathrm{TiO}_{2} @ \mathrm{~S}-1$ & $100 \%(360 \mathrm{~min})$ & $100 \%(360 \mathrm{~min})$ & $0 \%(360 \mathrm{~min})$ \\
\hline
\end{tabular}

*S-1 represents zeolite

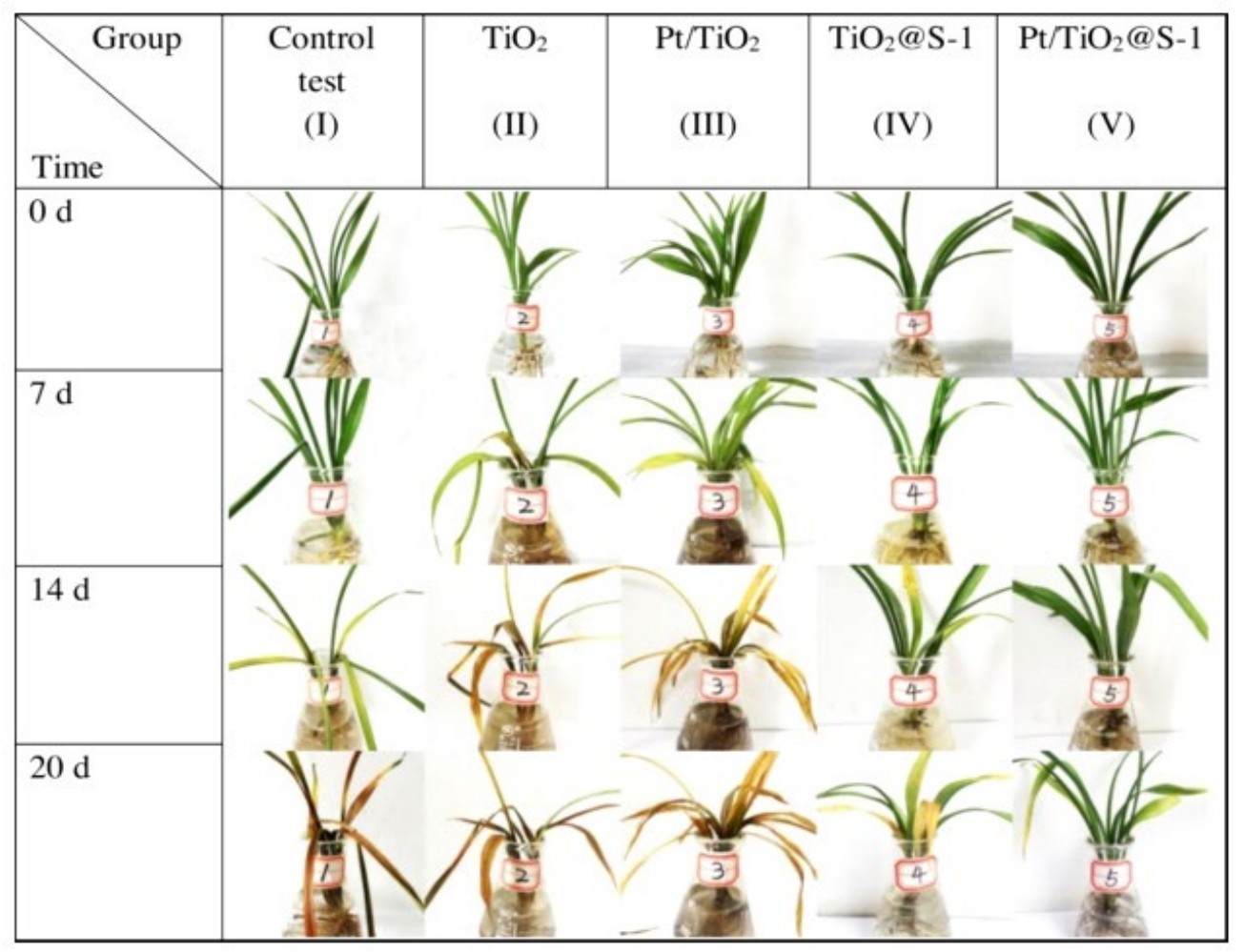

Figure 1: Photographs of the grasses under different conditions [3]

\section{Modification of Zeolite for Photocatalytic Enhancement}

Many researchers were discovered the capabilities of zeolite used as adsorbents and photocatalyst in the photocatalytic performance for suspension solution as listed in Table 3. As mentioned by EsmailiHafshejani and Nezamzadeh-Ejhieh in 2016 [4], the photodegradation efficiency was increased by using zeolites as catalyst due to the adsorption capacity of zeolites can cause to bring molecules of organic pollutant near the catalyst surface where hydroxyl and superoxide radicals produced.

There are two types of zeolite, which are synthetic and natural zeolites. Mostly, they are widely used as supported materials of semiconducting materials such as Ag halides [5], zinc oxide [6] and nickel [7] in order to enhance the photocatalytic activity. Admittedly, the sizes and shapes of zeolites could influence the zeolite properties and catalytic performances and subsequently enhanced the catalytic performance for many reactions [8].

Besides, zeolite also acts as preventing aggregation materials for the semiconductors which significantly increase the effective surface area. Additionally, the presence of Lewis acid-base sites in zeolite structure can cause to distribution of photogenerated electrons in zeolite framework which significantly decrease electron/holes recombination. 
Table 3: Zeolite modification using various methods for photocatalytic enhancement

\begin{tabular}{|c|c|c|c|}
\hline Modification Method & Parameter & Remarks & Ref. \\
\hline $\begin{array}{l}\text { Hydrolysis deposition method and } \\
\text { calcination crystallization process }\end{array}$ & Effect of acid leaching & $\begin{array}{l}\text { High degradation rate due to higher surface area, more surface hydroxyl } \\
\text { groups and excellent dispersion effect of the acid leaching zeolite }\end{array}$ & [9] \\
\hline Hydrothermal method & $\begin{array}{l}\text { Different aluminium } \\
\text { sources }\end{array}$ & $\begin{array}{l}\text { Zeolite products prepared using aluminium isopropoxide could degraded } \\
\text { methylene blue (MB) dye with } 85 \% \text { and } 100 \% \text { within } 180 \text { and } 110 \mathrm{~min} \text { in the } \\
\left.\text { presence of UV and (UV+ } \mathrm{H}_{2} \mathrm{O}_{2}\right) \text {, respectively. }\end{array}$ & {$[10]$} \\
\hline $\begin{array}{l}\text { Solid state dispersion (SSD) } \\
\text { method }\end{array}$ & $\begin{array}{l}\text { Amounts of } \mathrm{TiO}_{2} \text { doped } \\
\text { microporous zeolite SSZ-13 }\end{array}$ & $\begin{array}{l}\text { With } 60 \% \text { loading } \mathrm{TiO}_{2}, \mathrm{H}_{2} \text { generation enhanced for } 3 \text { times compare to } \mathrm{P} 25 \\
\text { and degradation rate of } \mathrm{MB} \text { was } 96 \% \text { within } 2.5 \mathrm{~h} \text {. }\end{array}$ & {$[11]$} \\
\hline Sol gel method & $\begin{array}{l}\text { Series of } \mathrm{TiO}_{2} / \text { zeolites } \\
\text { catalysts }\end{array}$ & $\begin{array}{l}\text { An appropriate porous structure and framework of } \mathrm{TiO}_{2} / \mathrm{ZSM}-5 \text { with } \mathrm{Si} / \mathrm{Al} \\
\text { ratio of } 200 \text { achieved the best catalytic activity which led to superior capacity } \\
\text { for benzene absorption and ozone decomposition. }\end{array}$ & {$[12]$} \\
\hline Hydrothermal method & $\begin{array}{l}\text { Varying assistant reagent } \\
\text { and } \mathrm{BiPO}_{4} \text { nanoparticles }\end{array}$ & $\begin{array}{l}\text { The optical properties and photocatalytic activities on the decoloration of MB } \\
\text { under UV light irradiation by using } \mathrm{BiPO}_{4} / \text { zeolite was influenced by the } \\
\text { morphology structure formed. }\end{array}$ & {$[13]$} \\
\hline $\begin{array}{l}\text { Surface sprayed and intermixed } \\
\text { methods }\end{array}$ & $\begin{array}{l}\text { Different dosages of Zeolite } \\
\text { fly ash bead }(\mathrm{ZFAB}) / \mathrm{TiO}_{2}\end{array}$ & $\begin{array}{l}\text { The addition of } \mathrm{ZFAB} \text { could improve the exposure degree of } \mathrm{TiO}_{2} \text { particles in } \\
\text { cement matrix surface. The incorporation methods and dosages of } \mathrm{ZFAB} / \mathrm{TiO}_{2} \\
\text { was affected the exposure contents. }\end{array}$ & [14] \\
\hline $\begin{array}{l}\text { Modified procedure by Huang and } \\
\text { co-workers }\end{array}$ & $\begin{array}{l}\text { Effect of acid alkali } \\
\text { pretreated on zeolite }\end{array}$ & $\begin{array}{l}\text { Acid-alkaline pre-treatment and calcination at } 200^{\circ} \mathrm{C} \text { showed the best } \\
\text { performance attributed to its favourable surface structure and } \mathrm{TiO}_{2} \text { content. }\end{array}$ & {$[15]$} \\
\hline $\begin{array}{l}\text { Zeolite } \mathrm{Y} \text { treated using ammonium } \\
\text { acetate and ammonium fluoride }\end{array}$ & $\begin{array}{l}\text { Compare with parent } \\
\text { zeolite and pristine } \mathrm{TiO}_{2}\end{array}$ & $\begin{array}{l}\text { The photocatalytic degradation of methyl orange achieved } 92 \% \text { and } 7.6 \% \text { by } \\
\text { using } \mathrm{TiO}_{2} / \text { treated zeolite and } \mathrm{TiO}_{2} / \text { parent zeolite only, respectively. }\end{array}$ & {$[16]$} \\
\hline $\begin{array}{l}\text { 1. Cold-impregnation method } \\
\text { 2. In-situ method (hydrolysis) }\end{array}$ & $\begin{array}{l}\text { Fabricated nanosized } \\
\text { titanium/zeolite by different } \\
\text { method }\end{array}$ & $\begin{array}{l}\text { In-situ method showed the best characteristic properties of nanosized } \\
\text { titanium/zeolite for photocatalytic, adsorption and antibacterial. }\end{array}$ & {$[17]$} \\
\hline
\end{tabular}




\section{Zeolite in Membrane Fabrication}

Membrane fabrication was tailored by the selecting the appropriate fabrication methods. The addition of materials in the dope solution will affect membrane morphology and properties. Muntha, Kausar and Siddiq in 2016 reviewed the application and fabrication techniques of zeolite reinforced polymeric membranes. Their reviews only focused on four types of polymeric membranes which is polyimide, polysulfone, polycarbonate and mixed matrix membrane. The fabrication, procedure, working principle of zeolite reinforced polymeric membranes and the application in various areas such as medical, catalytic, gas separation and water purification have been discussed.

Saranya et al. [19] reported that the addition of zeolite nanoparticles up to $0.5 \mathrm{wt} \%$ make a significant in the growth of membrane sublayer porosity. The increment of zeolite amount in the membrane matrix could lead to sublayer macrovoids growth. Moreover, the unique pore structure and sharp pore size distribution of zeolites can be used for membrane fabrication by incorporating them into a polymer for better performance by means of molecular sieving and selective adsorption.

The incorporation of a low-cost natural zeolites into membrane matrix could effectively remove cations and hydrocarbons from simulated SAGD produced water stream as proven by Adamaref et al., [20]. The integration of natural zeolite in hollow fiber membrane contactors for removing ammonia from domestic wastewater effluents was discovered by Sancho et al. [21] where zeolites provide a framework structure with micro and mesopores.

The lignin-zeolite composite nanofibers membrane properties such as the tensile strength, tensile modulus, hydrophilicity, permeability and separation factor were influenced by addition of $1 \mathrm{wt} \%$ zeolite nanoparticles as revealed by Bahi et al., [8]. They mentioned that the improvement of mechanical properties such as strength and modulus of nano-fibrous membranes were achieved by the addition of an appropriate zeolite nanoparticles dispersed uniformly in the lignin nanofibers suppressed the macrovoids and improved the interaction between inorganic particles and polymers.

Asvadi et al. in 2017 [22] fabricated a multi-layer zeolite X/ polyvinyl alcohol (PVA)/ polyethersulfone (PES) membrane via electro-spraying of nano zeolite $\mathrm{X}$ particles with varying zeolite layer thickness $(2.5,5.0,10.0 \mu \mathrm{m})$ and concentration $(2.5,5$ and $7.5 \mathrm{wt} \%)$. They also varied the PVA layer thickness in order to increase the surface energy and adhesion of the inorganic layer. They found out that the hydrophilicity of multi-layer membranes increased with the addition of zeolite particles due to the active site in the zeolite $\mathrm{X}$ and leads to higher permeation flux through the membrane. As depicted in Figure 2a, three different layers of prepared membrane were formed and the zeolite layer as the selective top layer completely covered the whole membrane surface (Figure $\mathbf{2 b}$ ).
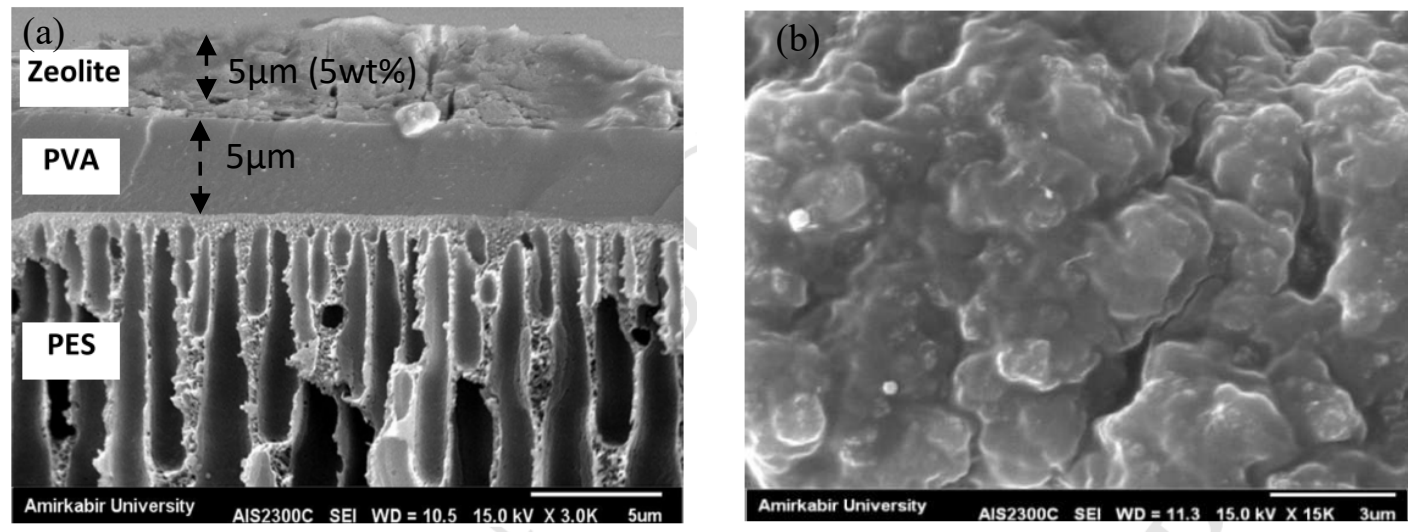

Figure 2: (a) The cross section and (b) top surface of multi-layer nano zeolite X/PVA/PES membrane [22]

As proven by Dzinun et al., 2019 [23], clinoptilolite (TCP) can be integrated with titanium dioxide $\left(\mathrm{TiO}_{2}\right)$ to produce photocatalyst in powder form using solid state dispersion method (SSD). They embedded $\mathrm{TiO}_{2} / \mathrm{TCP}$ composite photocatalyst powder at the outer layer of dual layer hollow fiber (DLHF) membrane via single step co-spinning process. They mentioned that the presence of TCP at 
the outer layer could increase the thickness of DLHF - TCP membranes due to large particle size of TCP.

\section{Zeolite Performance in Photocatalytic Application}

Nassar \& Abdelrahman in 2017 found out that the prepared zeolite nanostructures could be simultaneously used as adsorbents and photocatalysts for the methylene blue (MB) removal [10]. The prepared zeolite nanostructures using sodium aluminate achieved $100 \%$ degradation within 180 min in the absence of $\mathrm{H}_{2} \mathrm{O}_{2}$. Besides, the enhancement of photocatalytic activity achieved by the addition of acid leaching in $\mathrm{TiO}_{2} /$ zeolite composite preparation.

Clinoptilolite incorporated in thin film nanocomposites (TFN) with embedded into polyamide (PA) layer of reverse osmosis (RO) membranes. Taking the hydrophilic properties of clinoptilite, the water flux improved without an intensive loss of salt rejection under high pressure during RO process [24]. Rezaei and Mehrnia in 2014 investigated the effects of clinoptilolite addition on sludge characteristics, fouling mitigation and nutrient removal in a membrane bioreactor (MBR) [25].

Besides, clinoptilolite also incorporated with $\mathrm{TiO}_{2}$ nanoparticles to produce $\mathrm{TiO}_{2} / \mathrm{TCP}$ composite photocatalyst and then embedded at the outer layer of DLHF membranes for photocatalytic applications [23]. From their results, it can be concluded that TCP have the capability to improve the photocatalytic performance and increased the pollutant removal and permeability of DLHF membrane as well.

\section{Conclusion}

This review presents the results based upon zeolite as support materials, and functionally as adsorbents and photocatalyst in the photocatalytic applications. Most of the researchers also tried to modify zeolite using various methods in order to enhance the photocatalytic performances. Distinctly, the addition of zeolite in membrane fabrication could improve the membrane properties and subsequently increased the membrane performances. Thus, it can be concluded that zeolite can be effectively used for photocatalytic applications by incorporating with other materials and membrane properties enhancement.

\section{Acknowledgement}

This research was made possible by funding from research grant number K168 Fundamental Research Grant Scheme for Research Acculturation of Early Career Researchers (FRGS-RACER) provided by the Ministry of Higher Education Malaysia and Universiti Tun Hussein Onn Malaysia (UTHM) Tier 1 Grant (H244). The authors would also like to thank the Research Management Centre, UTHM for their technical support.

\section{References}

[1] "A zeolite's three-dimensional structure is built up by linking together silicate [SiO4I4- and aluminate [A10415- tetrahedra (Figure 2. la), by the sharing of oxygen atoms at all four corners.," Representations, pp. 230-241.

[2] A. Corma and H. Garcia, "Zeolite-based photocatalysts," Chem. Commun., no. 13, p. 1443, 2004.

[3] R. Ma, L. Wang, S. Wang, C. Wang, and F. S. Xiao, "Eco-friendly photocatalysts achieved by zeolite fixing," Appl. Catal. B Environ., vol. 212, pp. 193-200, 2017.

[4] J. Esmaili-Hafshejani and A. Nezamzadeh-Ejhieh, "Increased photocatalytic activity of $\mathrm{Zn}(\mathrm{II}) / \mathrm{Cu}$ (II) oxides and sulfides by coupling and supporting them onto clinoptilolite nanoparticles in the degradation of benzophenone aqueous solution," J. Hazard. Mater., vol. 316, pp. 194-203, 2016. 
[5] S. Jafari and A. Nezamzadeh-Ejhieh, "Supporting of coupled silver halides onto clinoptilolite nanoparticles as simple method for increasing their photocatalytic activity in heterogeneous photodegradation of mixture of 4-methoxy aniline and 4-chloro-3-nitro aniline," J. Colloid Interface Sci., vol. 490, no. 2017, pp. 478-487, 2017.

[6] M. Bahrami and A. Nezamzadeh-Ejhieh, "Effect of the supported $\mathrm{ZnO}$ on clinoptilolite nanoparticles in the photodecolorization of semi-real sample bromothymol blue aqueous solution," Mater. Sci. Semicond. Process., vol. 30, no. 2015, pp. 275-284, 2015.

[7] M. H. Sheikh-Mohseni and A. Nezamzadeh-Ejhieh, "Modification of carbon paste electrode with Ni-clinoptilolite nanoparticles for electrocatalytic oxidation of methanol," Electrochim. Acta, vol. 147, no. 2014, pp. 572-581, 2014.

[8] A. Bahi, J. Shao, M. Mohseni, and F. K. Ko, "Membranes based on electrospun lignin-zeolite composite nanofibers," Sep. Purif. Technol., vol. 187, no. 2017, pp. 207-213, 2017.

[9] G. Zhang, A. Song, Y. Duan, and S. Zheng, "Enhanced photocatalytic activity of TiO 2 /zeolite composite for abatement of pollutants," Microporous Mesoporous Mater., vol. 255, no. 2018, pp. 61-68, 2018.

[10] M. Y. Nassar and E. A. Abdelrahman, "Hydrothermal tuning of the morphology and crystallite size of zeolite nanostructures for simultaneous adsorption and photocatalytic degradation of methylene blue dye," J. Mol. Liq., vol. 242, pp. 364-374, 2017.

[11] Y. Wang, J. Chen, X. Lei, and Y. Ren, "Preparation of microporous zeolites TiO2/SSZ-13 composite photocatalyst and its photocatalytic reactivity," Microporous Mesoporous Mater., vol. 250, no. 2017, pp. 9-17, 2017.

[12] H. Huang et al., "Photocatalytic Oxidation of Gaseous Benzene under VUV Irradiation over TiO2/Zeolites Catalysts," Catal. Today, vol. 281, no. 2017, pp. 649-655, 2017.

[13] H. Yu, T. Cui, and Z. Liu, "Photocatalytic activity of different morphology BiPO4 supported on zeolite," J. Energy Chem., vol. 25, no. 4, pp. 621-626, 2016.

[14] L. Yang, F. Wang, D. Du, P. Liu, W. Zhang, and S. Hu, "Enhanced photocatalytic efficiency and long-term performance of $\mathrm{TiO} 2$ in cementitious materials by activated zeolite fly ash bead carrier," Constr. Build. Mater., vol. 126, pp. 886-893, 2016.

[15] D. Kanakaraju, J. Kockler, C. A. Motti, B. D. Glass, and M. Oelgemöller, "Titanium dioxide/zeolite integrated photocatalytic adsorbents for the degradation of amoxicillin," Appl. Catal. B Environ., vol. 166-167, no. 2015, pp. 45-55, 2015.

[16] K. Guesh, C. Márquez-Álvarez, Y. Chebude, and I. Díaz, "Enhanced photocatalytic activity of supported TiO2 by selective surface modification of zeolite y," Appl. Surf. Sci., vol. 378, no. 2016, pp. 473-478, 2016.

[17] E. Domoroshchina, G. Kravchenko, and G. Kuz'micheva, "Nanocomposites of zeolitetitanium(IV) oxides: Preparation, characterization, adsorption, photocatalytic and bactericidal properties," J. Cryst. Growth, vol. 468, no. February, pp. 199-203, 2017.

[18] S. T. Muntha, A. Kausar, and M. Siddiq, "A Review on Zeolite Reinforced Polymeric Membranes: Salient Features and Applications," Polym. Plast. Technol. Eng., vol. 2559, no. July, p. 03602559.2016.1185631, 2016.

[19] R. Saranya, G. Arthanareeswaran, A. F. Ismail, N. L. Reddy, M. V. Shankar, and J. Kweon, "Efficient rejection of organic compounds using functionalized ZSM-5 incorporated PPSU mixed matrix membrane," RSC Adv., vol. 7, no. 25, pp. 15536-15552, 2017.

[20] S. Adamaref, W. An, M. O. Jarligo, T. Kuznicki, and S. M. Kuznicki, "Natural clinoptilolite composite membranes on tubular stainless steel supports for water softening," Water Sci. Technol., vol. 70, no. 8, pp. 1412-1418, 2014

[21] I. Sancho, E. Licon, C. Valderrama, N. de Arespacochaga, S. López-Palau, and J. L. Cortina, 
"Recovery of ammonia from domestic wastewater effluents as liquid fertilizers by integration of natural zeolites and hollow fibre membrane contactors," Sci. Total Environ., vol. 584-585, pp. 244-251, 2017.

[22] F. Asvadi, A. Raisi, and A. Aroujalian, "Preparation of multi-layer pervaporation membrane by electro-spraying of nano zeolite X," Microporous Mesoporous Mater., vol. 251, pp. 135-145, 2017.

[23] H. Dzinun, M. H. D. Othman, A. F. Ismail, "Photocatalytic performance of TiO2/Clinoptilolite: Comparison study in suspension and hybrid photocatalytic membrane reactor." Chemosphere, 228, 241-248, 2019.

[24] M. Safarpour, V. Vatanpour, A. Khataee, H. Zarrabi, P. Gholami, and M. E. Yekavalangi, "High flux and fouling resistant reverse osmosis membrane modified with plasma treated natural zeolite," Desalination, vol. 411, pp. 89-100, 2017.

[25] M. Rezaei and M. R. Mehrnia, "The influence of zeolite (clinoptilolite) on the performance of a hybrid membrane bioreactor," Bioresour. Technol., vol. 158, no. 2014, pp. 25-31, 2014. 